\title{
Relações de poder e bem comum na Baixa Idade Média Italiana (séc. XIII-XIV)
}

André Luis Pereira Miatello*

Resumo: Este artigo pretende discorrer sobre o entendimento de bem comum/ utilidade comum nas práticas políticas da Baixa Idade Média. O interesse volta-se para a discussão acerca da possibilidade de haver ação política e esfera política no período medieval e de saber como esses elementos constituíam critérios de sociabilidade e governabilidade. Compreende-se bem comum como categoria ordenadora do agir civil, mas que transcende os agentes históricos e as instituições: o bem comum constitui a referência de práticas que visam à utilidade comum que, tangível aos cidadãos e às instituições, possibilita a vida coletiva e a justiça social. Palavras-chave: Bem comum. Utilidade comum. Política. Cidade.

\section{Introdução}

Bonum commune e communis utilitas. Duas expressões de claro sabor político que, no século XIII, na Itália e fora dela, marcaram de maneira exaustiva os discursos dos agentes de governo, bem como as práticas sociais de comunidades políticas muito concretas (MILANI, 2006, p. 46); duas expressões fortemente ancoradas na tradição política ocidental desde os tempos de Aristóteles, o que já é bastante para assegurar seu uso irrestrito, mas também presentes na formulação teológica cristã, do Novo Testamento em diante

\footnotetext{
* Professor Adjunto de História Medieval na Universidade Federal de Minas Gerais. Pesquisa financiada pela Pró-Reitoria de Pesquisa da UFMG. E-mail: andremiatello@gmail.com
} 
(COLLARD, 2010, p. 227). Termos elásticos e polissêmicos que, ao lado de outros como paz, justiça e concórdia, permitiram os usos mais variados, consoante os ventos da história, ora para justificar um poder tradicional ameaçado, ora para fundamentar mudanças nas estruturas de poder (ZORZI, 2008, p. 68). A aparente neutralidade de termos tão excelsos sempre foi posta a serviço de causas muito precisas, tragada pelo vórtice dos conflitos sociais que, em âmbito italiano, redundaram em troca de sistema político, competição partidária, retaliação e guerras civis.

Ao querer tratar de aspectos do político, que "[...] pode ser definido como uma esfera de atividades caracterizada por conflitos irredutíveis" (ROSANVALLON, 2010, p. 42), a compreensão histórica das expressões bem comum e utilidade comum oferece-nos a chance de superar, ou ao menos de ultrapassar, os limites das fontes eruditas, marcadamente teóricas, e considerar as fontes da prática, aí contemplados os sistemas de governo, as ações sociais de diversos atores históricos, os discursos do poder e as práticas que colocam em causa o poder, o instauram e remodelam. Além disso, somos impelidos a tomar a peito uma consideração mais ampla acerca da possibilidade de ação propriamente política numa época (a "medieval") em que os críticos tendem a negar qualquer conhecimento do significado de polis/civitas que não seja uma mera apropriação de vocabulário. É o que encontramos, por exemplo, em Hannah Arendt, quando tenta estabelecer os critérios que distinguem as esferas pública e privada, n'A condição bumana:

O conceito medieval de "bem comum", longe de indicar a existência de uma esfera política, reconhecia apenas que os indivíduos privados têm interesses materiais e espirituais em comum, e só podem conservar sua privatividade e cuidar de seus próprios negócios quando um deles se encarrega de zelar por esses interesses comuns (ARENDT, 2007, p. 44).

De uma tacada só, Arendt nega que as sociedades medievais, aí incluídos os reinos, principados e repúblicas citadinas, tenham sido, de fato, esferas políticas e, ao mesmo tempo, que seus sistemas de organização social tenham favorecido ações políticas. 
Obviamente, Arendt reconhece que "[...] a esfera secular, sob o feudalismo, era, de fato, em sua inteireza, aquilo que a esfera pública havia sido na antiguidade" (ARENDT, 2007, p. 43); no entanto, tal observação em nada abona sua opinião acerca da "privatização da política" no âmbito daquilo que ela mesma chama de feudalismo, sem maiores esclarecimentos. Ora, dá-se por descontado que a autora redigiu $A$ condição humana, em 1958, época em que historiadores medievalistas como Georges Duby e Jacques Le Goff pensavam de modo semelhante. Mas, Arendt problematiza a questão: para ela, o senhor castelão não era parecido com o paterfamilias, o chefe da domus romana, porque aquele podia exercer a justiça punitiva dentro do espaço da castelania, enquanto na domus (o espaço doméstico romano) não havia justiça, mas domínio. Há o reconhecimento de que a castelania exerce a justiça, o que, numa compreensão antiga, é atributo da polis/civitas, mas evita-se concluir que este espaço e esta ação tenham sido propriamente políticos, porque, segundo a autora, o feudalismo trouxe para o espaço privado aquilo que nos gregos acontecia no espaço público.

Não se trata de refutar o entendimento proposto por Arendt, mas relevar categorias que, na chamada Idade Média ocidental, marcaram a ação social num âmbito extradoméstico. Há algo de positivo e afirmativo no que tange, por exemplo, ao governo e ao exercício de poder que nos leva a discordar da ideia de privatização da política. Vejamos, à guisa de introdução, uma pequena mostra: Alcuíno de York (735-804), importante erudito da corte carolíngia, escreveu o diálogo Disputatio de rhetorica et virtutibus, para mostrar o lugar da oratória na vida cotidiana do rei franco, no caso, Carlos Magno: é um manual de como aprender a usar a retórica no exercício do poder régio e no governo do reino. Alcuíno escreve logo no início: "Quem deseja conhecer os costumes políticos [civiles mores] leia os preceitos contidos neste livro (Disputatio de rhetorica, 1) Segundo os termos do diálogo, o próprio rei reconhece que a retórica se ordena ao exercício político: “[...] todo o seu propósito versa sobre questões civis" [totam eius artis vim in civilibus versari quaestionibus], o que nos leva a notar que (1) existe uma retórica civil (não só eclesiástica) na Alta Idade Média, (2) que essa retórica é ferramenta necessária ao exercício de governo e (3) que o 
governante reconhece que deve saber lidar com essa técnica. A leitura do diálogo coloca-nos diretamente em contato com a obra de Cícero, sobretudo o De oratore; e pode-se dizer, apoiado em Stephen Jaeger (1994, p. 31) que Alcuíno adaptou para Carlos Magno a figura do orador que Cícero havia proposto a seus contemporâneos.

Talvez Alcuíno, ou o próprio Carlos Magno, estivesse empregando os termos civiles mores ou civiles quaestiones num sentido muito diferente daquele de Cícero e da tradição política romana; talvez, fosse apenas um preciosismo erudito de homens saudosos de um passado ilustre. No entanto, permanece o fato de que a cultura régia carolíngia sabia atribuir valores diferentes para o espaço doméstico da corte régia e para seu espaço público e que, no exercício de governo, a retórica, a arte de falar em público, não em privado, constituía não só um instrumento, mas uma necessidade. É a partir de pistas como esta que espero apresentar algumas reflexões sobre a ação política na Baixa Idade Média, tendo por objeto a compreensão de bem comum/utilidade comum; irei priorizar a experiência histórica das cidades italianas não por crer que tenha sido lá que a política veio a renascer das cinzas, mas porque foi no embate ideológico dos partidos ${ }^{1}$ que compunham a cidade [civitas/ communitas] que o discurso do bem comum tornou-se uma verdadeira obsessão daqueles que agiam politicamente. Na tentativa de problematizar a questão, irei percorrer uma documentação variada que inclui tratados retóricos, atos da prática, sermões e tratados sobre arte de governar: espero ultrapassar o limite da teoria proposta para vislumbrar as práticas sociais decorrentes da noção social de bem comum.

\section{Retórica e política}

As cidades comunais italianas, no século XIII, eram aquelas que possuíam uma carta de franquia exarada por um poder suprarregional, como o imperador ou o papa, que garantia o autogoverno, a autonomia frente a outros poderes territoriais e o direito de aprovar estatutos e chancelar documentos a partir da própria autoridade citadina. O sistema de governo adotado por essas cidades 
assentava-se sobre duas instituições: o podestà [potestas, em latim, ou potentado, em português] como magistrado individual, um funcionário público contratado entre os cidadãos de outra cidade, e a cúria (ou conselho) que podia reunir entre 40 e 300 homens, dependendo do tamanho da cidade (ARTIFONI, 1994; GILLI, 2011; CAMMAROSANO, 2000). Ambas as instituições dependiam do uso do discurso como instrumento de persuasão; por um lado, a vida de assembleia elevou a retórica à condição de peça-chave do governo cívico; por outro lado, tornou necessário o aparecimento de profissionais da palavra, capazes de viverem pela cidade. Tratava-se de uma retórica muito prática e concreta: ensinar aos membros da cúria a cumprirem seu dever. Desse ponto de vista, a retórica era a alma das cidades comunais, pois a partir dela produziam-se os discursos de assembleia (concio) e as correspondências diplomáticas (ars dictaminis), atividades imprescindíveis para a organização política desses espaços.

A retórica no século XIII italiano não era só um conhecimento técnico, mas uma profissão (JANSEN, 2010, p. 157): a criação das comunas e a profissionalização da retórica permitiram que aparecesse a figura de leigos letrados em grande quantidade, espalhados pelos centros urbanos, homens disponíveis a trabalhar para os governos citadinos em troca de salário e reconhecimento social. Isso leva-nos a perceber que o sistema comunal italiano provocou uma mudança de paradigma social no âmbito da própria elite citadina, pois a vida política passou a exigir o domínio da retórica de todos aqueles que esperavam ser reconhecidos como boni homines, isto é, aristocratas. $\mathrm{O}$ estatuto nobiliárquico, antes ligado às questões sucessórias, dinásticas e patrimoniais sofreu, na Itália, uma inflexão que levou os homens de poder a se tornarem gradativamente homens de letras na medida em que possuir conhecimento retórico/livresco se tornou critério de ascensão social.

Entre os profissionais da palavra pública que se destacaram nas grandes cidades, como Florença, Siena, Bolonha e Pádua, estava Brunetto Latini (1220-c.1294), autor de vasta obra que lhe facultou, com justiça, ser contado entre os eruditos leigos mais fecundos do séc. XIII: todas as suas obras referem-se à retórica como ars civilis, que prefiro traduzir por ação política, evidente em dois domínios distintos: o discurso público oral (ars concionandi), prati- 
cado pelo orador de assembleia (concionator), e o discurso público escrito na forma de correspondência diplomática (ars dictaminis), praticado pelo dictator. Embora ambos os domínios suponham a perícia da palavra, Latini não esconde sua predileção pela ars dictaminis e pelo papel do dictator, segundo ele, bastante superior àquele de apenas saber discursar, mas não escrever. Neste texto, farei referência sobretudo à Rettorica, composta em vulgar toscano nos inícios da década de 1260, e aos Li Livres dou Tresor, escritos em provençal, quando Brunetto exilou-se no sul da França, entre 1260-1267. Chamo a atenção para o fato de que os professores de retórica, como Brunetto ou seu mestre Boncompagno de Signa (c.1170-c.1240), não eram apenas teóricos, como em França ou Inglaterra; ao contrário, eram homens de ação: ensinavam a governar e governavam, isto é, desempenhavam funções administrativas, como notários públicos (notarii), judiciais, como juízes (iudices) e de governo, como rectores (governantes): a lida direta nos afazeres administrativos e burocráticos marcou o tipo de literatura que produziram.

No entender de Latini, a retórica tem duplo sentido: aquele de bem falar (rhetorica), cujo especialista é o rhetor, e aquele de bem governar (regere), cujo especialista é o rector. Os homens do século XIII sabiam bem que uma atividade era diferente da outra, mas, para eles, era oportuna a confusão terminológica, pois afirmava aquilo que lhes parecia mais importante: o exercício do poder originava-se da capacidade comunicativa, isto é, no uso da palavra e da capacidade intelectiva, isto é, na posse de certa sabedoria (sapientia/ sapienzia) apta a reger os homens. O leitor atento deve ter notado o quanto Brunetto Latini foi influenciado por Cícero e sua teoria da fundação da civitas por um mítico homem sábio (vir sapiens) que, no princípio dos tempos, convencera os homens que se comportavam como selvagens (modo bestiarum vagabantur) de que era melhor viver em sociedade do que em isolamento e lhes ensinou as regras da vida comunitária. $\mathrm{Na}$ Rettorica de Brunetto, o homem sábio (uomo savio) funda a cidade mediante a sapienzia, mas precisa convencer os homens de que esta cidade oferece a vida boa e segura que desejam. Então, ensina os homens mediante a eloqueñia a terem fé, justiça, a obedecer uns aos outros, a terem noção do bem comum e a morrer em sua defesa.

O saber falar, aqui muito valorizado, pouco bem faria se fosse 
destituído da sabedoria que tempera as palavras. Tanto em Cícero, no De inventione, quanto em Brunetto Latini, na Rettorica, o homem sábio (vir sapiens/uomo savio) é capaz de fundar a cidade na medida em que fala com propriedade e possui as virtudes civis. Brunetto Latini, aliás, faz disso uma ocasião de crítica aos cidadãos florentinos de seu tempo: ocupavam um lugar destacado, aprenderam a arte do discurso, mas não adquiriram a sapienzৃia e, assim, ao invés de instaurar a cidade (cittade), estavam a destrui-la:

Houve homens tolos sem discrição que, vendo que alguns viviam em grande honra e possuíam alto status por conta de saber falar bem, segundo os mandamentos desta arte, dedicaram-se apenas em falar, esquecendo-se do estudo da sabedoria; e se tornaram tão copiosos no dizer que, pela abundância do muito falar sem o tempero de juízo, começaram a insuflar sedição e destruição nas cidades e nas comunas e a corromper a vida dos homens (MAGGINI, 1915 , p. $20-21)^{2}$.

Muito instrutiva esta percepção brunettiana: a palavra que funda a cidade também pode acabar com ela: nesse âmbito, conseguimos entender por que os retóricos, ao mesmo tempo em que escreviam tratados sobre o bem falar, também ensinavam a arte do saber ficar quieto (ars tacendi), como Albertano de Brescia (c. 1195c.1251), que, em 1245, escreveu a Doctrina dicendi et tacendi. Mas, a questão presente na referência de Brunetto parece-me ter ainda um sentido mais contundente: Brunetto opunha-se à confusão entre ser e parecer: o homem que sabe falar na assembleia (concionator) pretende se passar por sábio, não o sendo. Ele destrói a cidade justamente porque não é bom cidadão, não sendo sábio (ele tenta parecer que é, mas não é). Além disso, o falador tolo (folle) quer para si aquilo que não lhe pertence, isto é, a grande posição social que o sábio ocupa; na crítica brunettiana, vê-se que o concionator apresenta-se como o oposto do dictator (o retórico que domina a arte da escrita): ele quer aumentar o bem privado diminuindo o bem público, pois a glória que ele quer para si acarreta a sedição (sedizione) e a destruição (distruggimento) da cidade. O dictator, na medida em que 
é sábio não apenas na aparência, edifica a cidade, porque sabe dar o justo valor ao público e ao privado.

A proposta ciceroniana de eloquência e sabedoria, presente na Rettorica de Latini, coloca-nos diante do peso social que a oratória passou a ocupar na vida das cidades italianas. Magister Tolosano (m. 1226), cônego da catedral de Faenza, na Emília-Romagna, autor do Chronicon Faventinum, ajuda-nos a ter uma ideia disso, quando escreve: "Ubi nummoroum perorat pluralitas, ibi Tulliana tuba raucessit" (CAMMAROSANO, 2000, p. 432), que, numa tradução respeitosa do sentido da queixa, fica assim: "Onde é a proprina que discursa, ali o trombone de Cícero fica rouco": Tolosano dá a entender que a corrupção ditava o funcionamento do sistema político de Faenza, mas, ao mesmo tempo, que Cícero era o mestre da vida política e sua oratória o caminho ordinário de ação neste meio. Brunetto Latini, em Li Livres dou Tresor, insiste na mesma ideia:

Túlio diz que a mais alta ciência de governar a cidade é a retórica, isto é, a ciência do falar; pois se não fosse a fala, não haveria a cidade, nem nenhum estabelecimento de justiça nem de companhia humana (CARMODY, 1998, p. 317) 3 .

É seguindo as orientações de Cícero que Latini compara o tipo de governo urbano da França com aquele da Itália:

E isso se dá de duas maneiras: o que são de França e de outros países, são submetidos à senhoria dos reis e de outros príncipes perpétuos, que vendem os prebostados e os bailiados aos que podem pagar mais (pois eles procuram seu próprio bem, não o proveito dos burguenses; outro tipo existe na Italia, onde os cidadãos e os burguenses e as comunidades das cidades elegem o seu podestà (poesté) e seu senhor tal como eles creem que será mais proveitoso ao interesse comum da cidade e de todos os seus súditos (CARMODY, 1998, p. 392) ${ }^{4}$

A crítica que Brunetto dirige ao sistema monárquico consiste numa constatação pouco neutra: em França, os reis e príncipes ven- 
dem os cargos públicos a quem pode pagar mais, porque procuram atender ao interesse particular, e não ao coletivo; na Itália, a eleição dos magistrados obedece ao príncipio do interesse comum e, por essa razão, as comunas são elevadas acima das monarquias e oligarquias. $\mathrm{O}$ tema do interesse comum retorna logo no capítulo seguinte, no qual Brunetto aponta os três pilares que sustentam qualquer senhoria (signorie): justiça, reverência e amor (CARMODY, 1998, p. 392). A justiça deve existir no governante pela qual ele não se desvia nem para a direita nem para a esquerda e respeita os direitos de cada um ("il doinst a chascun son droit'); a reverência deve existir nos cidadãos e súditos: por ela se cumpre o mandato apostólico de honrar os superiores; o amor deve existir tanto no governante quanto nos governados

[...] pois os senhores devem amar seus súditos com grande coração e clara fé, e vigiar de dia e de noite pelo proveito comum da cidade e de todos os homens. Do mesmo modo, [os súditos] devem amar seu senhor de coração reto e com verdadeira intenção, e dar-lhe conselhos e ajuda para manter seu ofício (CARMODY, 1998, p. 392) . $^{5}$

O tema do amor que deve unir governantes e governados aparece na Eruditio regum et principum, que o frade minorita Gilberto de Tournai (c.1200-1284) escreveu ao rei de França Luís IX, em 1259, data muito próxima, portanto, da escrita do Tresor, de Latini. Segundo uma leitura foucaultiana (FOUCAULT, 2003), esse tema é uma das características do governo pastoral que, recentemente vem sendo discutido por Jacques Dalarun que, de resto, segue as linhas teóricas de Foucault; na obra Gouverner c'est servir: essai de démocratie médiévale (2012), Dalarun discorre sobre o papel das Ordens religiosas, em particular a Ordem dos Frades Menores, na composição de modelos políticos, vividos nos claustros, e baseados numa experiência democrática. O governo pastoral proposto por Foucault e Dalarun manifesta-se no modo infantilizado com que o governante lida com os governados, incapazes de sobreviver sem ele. Os governados amam seus governantes porque recebem tudo dele, segurança, alimento, assistência; em troca, obedecem-no sem questionamentos. 
Ora, o problema do pastorado parece-me bastante distante das ideias de Brunetto Latini: fala-se que o governante deve amar os súditos, porém esse amor aparece como forma de proteger o bem comum da cidade e de todos os homens. Latini não recorre ao amar "a todos e a cada um" (omnes et singulatim), que constitui o mote do governo pastoral. Além disso, os súditos, ao amar o governante, prestam-lhe ajuda e conselho, o que nos permite ver que esses subalternos não se submetem cegamente. Mas, pareceme que a grande objeção que Brunetto apresenta ao governo pastoral está no papel conferido à retórica como ato de governo: afinal, para quê saber falar se não para convencer? Se há necessidade de convencer é porque a obediência não é cega.

No âmbito citadino italiano, o tema do amor é também discutido pelo franciscano Paolino Minorita (c.1270-1344), autor de um tratado sobre o governo das cidades que, na edição crítica do século XIX, recebeu o título De regimine rectoris: o título latino disfarça o fato de o texto estar redigido no vulgar veneziano. Nesta obra, verdadeira propaganda do regime de governo de Veneza, a questão do amor que o rector deve nutrir aparece relacionado a uma lista de coisas a serem amadas numa sequência hierárquica: deve-se amar, em primeiro lugar, o bem maior do que todos, sem o qual nada pode ser bom, Deus. O amor pela cidade só é justo quando vem após o amor que se tem por Deus:

Depois sim, bom senhor, se deve amar a comunidade, porque, após o criador, a comunidade é melhor (coisa) porque ela compreende a bondade de todos os particulares, donde para defender este bem comum se deve colocar (à frente) cada (bem) particular assim como se põe a mão (à frente) para defender a vida de todo o corpo. Depois disso deve-se amar o que é melhor à comunidade seja pela oração, seja pelo conselho ou por ofício ou por artifício e isso exige a virtude de justiça, como se falou no capítulo IX (MUSSAFOA, 1868, p. 47) ${ }^{6}$.

A ideia de amor, politicamente concebido, e sua relação com o bem comum parece-me, nesse caso, muito próxima àquela de 
Brunetto e muito distante dos interesses do governo pastoral. Paolino Minorita, que adiante teremos ocasião de retomar, referese a uma situação precisa em que a comunanza pode vir a ser solapada por interesses partidários ou facciosos que podem pôr a perder a integridade do sistema: não se trata de uma autocracia pastoral, pois o rector, ao demonstrar que ama o bem comum, dá mostras de "[...] perseguir a utilidade da res publica inteira" (MILANI, 2006, p. 46) e é isso que lhe garante a legitimidade do governo. Também Brunetto vai nesta direção: a oratória que marca o governo comunal pressupõe que as decisões colegiadas sejam assumidas mediante a verbalização do bem/interesse comum; a colegialidade do sistema exige que, ao menos na teoria, o bem comum seja defendido nos discursos e, a partir deles, seja perseguido na ação política. A retórica, portanto, era a garantia de que o bem comum não seria vendido a quem pudesse pagar mais caro.

\section{O bem comum e a liberdade pessoal}

Estamos nos âmbitos da afirmação da comuna como sistema político novo que funciona em um espaço político antigo, tradicionalmente assentado no poder da aristocracia terratenente. $\mathrm{O}$ nascimento da comuna (aldeã ou citadina) é marcado pela ruptura da cidade/aldeia em relação aos senhorios da região, como o de um bispo ou conde ou abade que, a partir das curtes, isto é, os grandes domínios condais e monásticos, compunham a base organizativa principal (CASTAGNETTI, 1983; FOSSIER, 1993; MENANT, 2004; PANERO, 2008).

O território administrado por um conde, marquês ou abade abarcava uma série de comunidades submetidas à sua jurisdição que recebiam nomes diversos, como castrum, castellum ou sennoria o qual podemos traduzir por castelania. A castelania, por sua vez, congregava outras tantas localidades, bastante mais dispersas e juridicamente menos definíveis que conhecemos sob vários nomes, como vicus, villa ou burgus, a aldeia. As cidades, geralmente submetidas à jurisdição direta de um conde ou de um bispo, ou dos dois ao mesmo tempo, conviviam com as diversas modalidades de cas- 
telos e aldeias, ora mais ou menos autônomas em relação aos poderes locais. Desde o século XI, as cidades e aldeias do norte italiano iniciaram um processo de luta ou negociação com os antigos senhores, disputando com eles o acesso e o controle das terras consideradas públicas (pastos, bosques, estradas, feiras, igrejas) e dos recursos naturais (florestas, áreas de pesca, rios) que, segundo o direito consuetudinário (consuetudines), eram um tipo de propriedade coletiva.

A luta pela emancipação das aldeias e cidades, que deu origem às comunas, pode ser lida como luta pelo bem comum e este, a princípio, como categoria econômica: acesso aos espaços cultiváveis e às áreas de exploração comandados pelos condes, abades ou senhores de castelo. Desses embates, que se estenderam do séc. XI ao fim do séc. XII, surgiu uma consciência política nova, materializada pelas cartas de franquia e a consolidação de communitates (comunas, em português) que, mediante pressão e negociação, conseguiram dos senhores (conde, marquês, bispo ou abade) o direito de assembleia, podendo discutir e deliberar seus próprios rumos políticos, com mínima ou relativa interferência senhorial. Esta evidente emancipação aldeã e citadina incrementou o sentido econômico de bem comum, tornando-o uma categoria política, visível no direito de assembleia, na escolha e atividade de consules (representantes da nova elite comunal em consonância com a antiga elite senhorial') e na aquisição de certos direitos concedidos pela carta de franquia, como a recolha de alguns impostos e no tribunal da comuna.

Tomemos um caso particular, o da comuna de Bolonha, em meados do século XIII; analisemos um documento de grande importância nesse processo de definição de políticas coletivas visando à defesa da liberdade comunal e de seus valores. O Liber Paradisus, uma lista detalhada dos nomes de todos os escravos que foram libertados pela comuna em 1257, pode ser muito útil às nossas demandas. É uma carta de manumissão, portanto, com um sentido muito preciso, aquele da concessão de liberdade pessoal, mediante resgate, mas que acompanha um outro processo de aquisição de liberdade, aquele coletivo, referente à comuna como um ente jurídico autônomo (a carta de franquia). Várias cidades e aldeias, desde o fim do século XII e começo do XIII, ao conquistarem cartas de franquia, 
concederam logo após cartas de manumissão aos escravos, pagando o preço deles aos antigos senhores (CASTAGNETTTI, 1983, p. 48).

François Menant (2007) observa que a Itália tem centenas de cartas de franquia, mas apenas uma ínfima minoria possui um prólogo ou preâmbulo no qual os autores costumavam inserir considerações mais amplas acerca da liberdade conquistada ou concedida; uma das exceções é justamente o Liber Paradisus, que não é carta de franquia, mas participa do gênero. A manumissão em Bolonha ocorreu em 3 de junho de 1257 e o número de escravos libertados chegou a 5.855. Esta não foi a primeira vez que houve manumissão na cidade, mas foi a primeira em que esse ato foi tomado pela comuna, enquanto ente político constituído por comum deliberação. Foi também a primeira vez que a decisão foi assumida como parte dos estatutos da cidade, ou seja, como ato legislativo celebrado publicamente. O grande autor do ato foi Bonacursio de Soresina, um aristocrata cremonês eleito capitão do povo, em Bolonha, entre 1256-1257.

A comuna pagou oito liras para alforriar os escravos menores de quatorze anos e dez liras pelos maiores, sem distinção entre homens e mulheres: há estimativas que dizem que os valores pagos correspondiam ao preço de um boi ou de um cavalo no mercado de Bolonha. Os gastos chegaram, então, a 53.014 liras, quantidade que seria paga em parcelas, de 1257 até 1259: os donos dos escravos eram 379, membros de ambos os partidos que compunham a comuna, isto é, os Geremei (tradicionalmente relacionados com os Guelfos) e os Lambertazzi (Gibelinos). Na opinião de Antonio Ivan Pini (1996), a manumissão dos escravos de Bolonha não foi consequência da luta entre senhores e escravos, o que significaria uma revolta antiescravista, mas resultado da luta entre a comuna, enquanto jurisdição citadina, e os senhores do contado, a zona extraurbana dividida em vários senhorios. Nota-se o quanto foi custoso o modo pelo qual a comuna bolonhesa conseguiu se impor sobre o campo (contado) circunvizinho.

O gesto de libertação dos escravos de Bolonha teve um duplo sentido. O primeiro deles é o jurídico: era a primeira vez que a comuna interferia no âmbito propriamente legislativo. Devemos levar em conta a diferença entre ius commune (as leis) e ius proprium (os 
estatutos): as comunas italianas tinham direito a gerir o ius proprium, instituindo estatutos municipais; não podiam elaborar ou impor leis, pois isso era jurisdição imperial. A manumissão aconteceu por meio de ato legislativo e, portanto, significou uma interferência no âmbito imperial. O segundo sentido é o econômico: com a manumissão dos 5.855 escravos, a comuna passou a contar com 5.855 novos contribuintes, uma vez que os escravos eram isentos de impostos. Desse modo, os gastos despendidos com o pagamento do resgate, que trouxeram impacto aos cofres públicos, seriam devidamente compensados com a inserção dos libertos no sistema fiscal da cidade. Tomemos um dos prólogos que compõem o Liber Paradisus de Bolonha, aquele da Porta São Próculo:

[Sobre o bairro da Porta São Próculo]. No princípio, o Senhor Deus onipotente plantou o paraíso da vontade e nele colocou o homem que formou, cujo corpo ornou de vestes esplendorosas, dando-lhe perfeitíssima e perpétua liberdade. Porém, aquele miserável [i.é, Adão], esquecendo-se de sua dignidade e das graças divinas, comeu o fruto que o preceito do Senhor vetara, donde levou ele mesmo e toda a sua posteridade a este vale miserável e contaminou inteiramente o gênero humano e o atou miseravelmente com laços diabólicos da servidão e assim, de incorruptível que era, fez-se corruptível, de imortal, fez-se mortal, incorrendo na mutação e gravíssima servidão. [...] Em consideração dessas coisas (isto é, a queda do homem e a sua libertação em Cristo), a cidade de Bolonha que sempre lutou pela liberdade, recordando-se dos antigos e prevendo as coisas futuras, em honra de nosso redentor e senhor Jesus Cristo, resgatou a todos os que, na cidade e no bispado de Bolonha, foram encontrados inscritos em condição servil e decretou sua liberdade, por meio de uma diligente inquirição, estabelecendo que ninguém permaneça adscrito em alguma servidão na cidade ou no bispado de Bolonha, para que a massa, tanto a da liberdade natural quanto a resgatada com dinheiro, não possa ser corrompida por algum fermento de servidão, pois um pouco de fermento corrompe toda a massa e o conluio de uns poucos maus estraga muitos 


\section{André Luis Pereira Miatello}

bons. [...] este memorial deve ser chamado propriamente de Paraíso: contém os nomes dos senhores, dos escravos e também das escravas para que fique patente quais escravos e escravas foram libertos e a que preço, isto é, 10 libras de Bolonha pelos maiores de 14 anos, escravo ou escrava, e 8 libras pelos menores. [...] (GAT'TA; PLESSI, 1956, p. 5-6) ${ }^{8}$.

Este prólogo dá-nos outras tantas pistas sobre o valor da retórica para as ações públicas da comuna: mobilização de argumentos, como a narrativa de Gênesis e da encarnação de Cristo. O texto leva o leitor a entender que o homem, sozinho, cava a própria cova, mas, com Deus, resgata a antiga natureza, já que a salvação não é esforço humano, mas dom divino. No texto, a comuna ocupa a posição de intermediária da ação da graça: ela pode, concretamente, permitir que a graça liberte os homens concretos. Em outras palavras, é como se a comuna fizesse o discurso teológico da redenção, aquele que propunha a escravidão como consequência do pecado, tornar-se ato político e histórico, como se a comuna desse carne e sangue à doutrina.

A comuna que emerge do Liber Paradisus é uma comuna soteriológica: ela reverteu o efeito do pecado enquanto ato da razão humana que age autonomamente, sem referência a Deus e, ao mesmo tempo, permitiu que a graça iluminasse a razão. A comuna não é como Babilônia, construída por Nemroth (contaminado pela ambição de dominar), mas como a Nova Jerusalém, construída por Cristo, pelo vínculo da caridade. Querendo ou não querendo, os autores do Liber Paradisus evocaram uma série de referências teológicas que podem aqui ser ligadas ao aspecto político da religião. Adão e Eva agiram individualmente e conseguiram a escravidão; os bolonheses agiram coletivamente e conseguiram a libertação. Individualidade/coletividade; espaço privado/espaço público: a balança parece pender para o segundo lado.

A existência de escravo supõe a existência de senhor: no caso do Liber Paradisus, o esforço político da manumissão pretendia tornar Bolonha isenta de poder senhorial e, ao mesmo tempo, fazê-la senhora do contado, invertendo a antiga lógica. No nível da explicação bíblica em Gênesis, o homem natural era senhor de suas paixões 
Relações de poder e bem comum na Baixa Idade Média Italiana...

e senhor dos seres irracionais: o senhorio humano era a marca maior de sua condição de semelhança com Deus. Ora, Bolonha colocava-se na condição de cidade redentora, portanto, senhora, pois havia dominado suas paixões, isto é, equilibrado as forças políticas contrárias (os Geremei e Lambertazzi) e agora podia dominar o mundo à sua volta. Isso tudo é obviamente um discurso, um sonho; mas, com o dinheiro, pôde tornar-se um pouco realidade.

\section{Os bens comunais e a disputa partidária}

Se a consideração do bem comum leva-nos, o mais das vezes, para o campo teórico ou moral, o mesmo não ocorre quando nos referimos aos bens comunais, que nos documentos italianos recebem nomes diversos, tais como communitates ou res communes. Esses bens formam um patrimônio que a comuna possui coletivamente, cujo acesso e uso também são geridos de forma coletiva. Antes de vermos o funcionamento desse sistema, observemos, antes, como ele se formou. Lembremos que as comunas (rurais ou urbanas) formaram-se no século XI, sobretudo pela compra ou confisco de boa parte das terras régias, geridas por representantes imperiais, como os condes, marqueses, bispos e abades. Esse patrimônio que constituía o fisco régio já estava acessível a certos cives, desde o séc. XI, que, por meio de privilégios reais, podiam usufruir das terras, principalmente aquelas ligadas à exploração natural, como florestas, cursos d'água e áreas alagadas. Esses cidadãos gozavam também de privilégios econômicos, como o direito de pesca ou isenção fiscal, como a dispensa de pagar o teloneum, imposto devido à entrada de mercadorias nas cidades (MAIRE VIGUEUR, 2004, p. 232). A fundação da comuna literalmente comunalizou esse patrimônio fundiário que, por meio de privilégios, formaram a base da propriedade coletiva da cidade, como vemos na expressão latina: arimannia et communibus rebus, em que arimanni é o termo usado nos textos italianos do séc. XI para indicar os cidadãos; arimannia refere-se à compreensão de cidadania, bem como aos direitos e deveres do conjunto dos cidadãos e res communis diz respeito a esse patrimônio coletivo.

A documentação mostra que esse patrimônio não era forma-

Anos 90, Porto Alegre, v. 20, n. 38, p. 181-217, dez. 2013 
do apenas por terras incultas, mas também por terras cultivadas; nesse caso, o resultado obtido com as colheitas ou o dinheiro arrecadado com o arrendamento das terras públicas era dividido entre os membros da comuna. Não parece exagerado considerar que os bens comunais, geridos coletivamente, eram a fonte de lucros mais ativa e promissora da cidade. Para entendermos um pouco melhor a relação entre bem comum e bens comunais, tomemos a bula Veri pacifici vestigia, exarada na chancelaria de Inocêncio III, em 21 de setembro de 1214, e a bula Gratiam gerimus, de Honório III, de 22 de fevereiro de 1218, todas relativas à comuna de Perúgia (GILLI; THÉRY, 2010, p. 442-451). Os textos permitem-nos acompanhar a gestão das propriedades comunais (communitates), a cobrança de imposto direto (collecta vel muttita) e a regulamentação da indenização devida aos cavaleiros por conta do prejuízo sofrido por seus cavalos de guerra (salvum equorum). Igualmente apreendemos o grande conflito que dividia a comuna de Perúgia entre os cavaleiros (milites) e o populus, isto é, o partido dos não cavaleiros (pedites); além da cisão política, Perúgia enfrentava grave crise financeira oriunda dos gastos de guerra com as cidades vizinhas, como Gúbio: não se tratava apenas de arcar com as despesas de guerra, mas, também, após os conflitos, indenizar os cavaleiros que lutaram pela comuna, pagando-lhes os prejuízos sofridos, na forma de emendatio. Ora, ter direito à indenização (emendatio) era a marca maior dos grandes privilégios que distinguiam os cavaleiros (milites) dos populares e que originavam os descompassos entre ambos os partidos, já que, para honrar com os compromissos da emendatio, a comuna precisava lançar mão de uma taxação extra, chamada collecta.

Cavaleiros e povo defendiam pontos de vista diametralmente opostos: nas bulas referidas, a cavalaria sempre aparece dotada de privilégios que ocasionam o descontentamento e repúdio dos populares que, apesar de não serem pobres, eram alijados de grande parte dos bens e serviços da comuna. A cavalaria urbana (militia) mostrava ser a classe dominante e dirigente por meio de privilégios, entre eles, o de controlar os bens comunais, de controlar a emendatio (salvum equorum), isto é, o dinheiro arrecadado para indenizar os próprios cavaleiros; a cavalaria tinha força política suficiente para impedir a reforma do sistema de tributação, pretendida pelos po- 
pulares, a reforma dos mecanismos de uso dos bens comunais e de fiscalização do dinheiro arrecadado com a emendatio. Os cavaleiros, portanto, tinham o privilégio de receber ajuda dos cofres públicos toda vez que fosse necessário, o que atingia o bolso do populus. Em poucas palavras, podemos dizer que a divergência entre cavaleiros e populares, em Perúgia, nasceu do abuso de poder e do acesso privilegiado aos cofres públicos por parte dos milites.

A gestão dos bens comunais, em Perúgia, obedecia à divisão populacional da cidade segundo o número de portas (5) e de paróquias (54): as portas, que correspondiam, mais ou menos, a uma repartição de grandes bairros (ou zonas urbanas), eram geridas por dois representantes eleitos, sendo que um, obrigatoriamente, devia pertencer à militia. $\mathrm{O}$ mesmo sucedia nas paróquias, nas quais um dos dois representantes também era cavaleiro. Esses representantes, quando necessário, eram responsáveis pela arrecadação da collecta, isto é, do imposto extra para a indenização da militia. A paróquia consta nas duas bulas papais como postos fiscais, como lugar de deliberação e votação, como arquivo de registro da população, pelo qual se podia distinguir o estatuto social de seus membros (milites/pedites) e o índice de riqueza de cada qual.

As terras comunais de Perúgia eram divididas segundo as cinco portas e, dentro de cada quinto da cidade, o patrimônio era dividido pelo número de paróquias: trata-se, portanto, de propriedade coletiva gerida coletivamente, pois cada paróquia podia usufruir de seu lote da maneira mais lucrativa, podia, inclusive, conceder a exploração dessas terras a quem pudesse pagar mais, em sistema de leilão. Além disso, as paróquias eram livres para assinar contrato com quem quisesse e o compromisso dos inquilinos (os usufrutuários) era garantido pelos fiadores (fideiussores).

O sistema regulador do uso dos bens comunais funcionava mais ou menos desse modo: o dinheiro arrecadado com o arrendamento das terras comunais parceladas por paróquias compunha um fundo comum para reparo dos prejuízos da militia; o dinheiro que sobrava era distribuído entre os núcleos da cidade (portas e paróquias). Vale notar que a cavalaria urbana manipulava esse fundo comum, criando modos de justificar um imposto especial e emergencial (collecta), ultrapassando a verba ordinária a ela destinada. A 
collecta prevista em 1214 era um imposto recolhido segundo uma taxa fixa estipulada por território (perparrochias), o que favorecia os mais ricos e prejudicava os mais pobres, porque a população não se distribuía planificadamente pelas paróquias: os cavaleiros, por exemplo, concentravam-se ao redor da ecclesia matrix (a catedral), enquanto os populares mais ricos estavam dispersos pelas paróquias mais centrais e os populares mais pobres nas paróquias periféricas.

Os membros do populus esperavam que a taxa da collecta respeitasse a divisão censitária, isto é, segundo a riqueza de cada cidadão (per libram), e não perparrochias, o que obrigava ricos e pobres a pagarem o mesmo valor. Os documentos papais mostram-nos que o papado sempre tomou o partido dos cavaleiros, mantendo a tradicional divisão paroquial como forma de estipular a tributação. O lucro advindo da gestão dos bens comunais repartia-se, como disse, entre as paróquias e portas e, delas, entre os habitantes (“[...] que todos os bens comunais [...] sejam divididos por portas e paróquias segundo a quantidade e qualidades dos homens") (MAIRE VIGUEUR, 2004, p. 220) ${ }^{9}$ : a divisão não é equitativa, mas qualitativa: privilegia os cavaleiros, certamente, mas é vista como compensatória, dado que as penalidades pelo descumprimento da lei eram também mais pesadas para os cavaleiros. Esta possível justificativa, no entanto, não satisfazia aos populares que continuavam prejudicados pela militia: a divisão dos lucros por paróquias não conseguia respeitar o preceito da qualidade dos homens, pois havia paróquias com muitos cavaleiros e outras com nenhum. Havia, portanto, um defeito no sistema que colocava uma paróquia contra a outra de modo que os dois representantes de cada porta eram com frequência pressionados a obter mais vantagens para aquelas zonas da cidade com mais cavaleiros.

A descrição da gestão dos bens comunais aponta-nos para as fragilidades da comuna, aí incluídos a corrupção, o uso ilícito dos recursos públicos e o abuso de poder. Jean-Claude Maire Vigueur (2004, p. 181) com justiça interpreta esse sistema de "privatização dos lucros e coletivização dos prejuízos", haja vista que os membros da militia, não só eram ressarcidos de seus prejuízos de guerra, bem como eram mantidos como camada dirigente pelo próprio dinheiro comunal, num processo contínuo de reprodução de classe, pois sem cavalo de guerra não há cavaleiro. A gestão dos bens co- 
Relações de poder e bem comum na Baixa Idade Média Italiana...

munais da cidade de Perúgia, segundo as discussões dos pregadores como Paolino Minorita e Giordano de Pisa, estava distante da noção de bem comum que, pela própria acepção proposta por eles, não podia sucumbir à predominância de um partido sobre o outro ${ }^{10}$. Vejamos, agora, como tais autores problematizaram a questão.

\section{Bem comum/utilidade comum e o mal das riquezas}

Paolino Minorita foi um dos que tomaram a peito a discussão sobre as aproximações entre a teoria do bem comum e a prática da gestão dos bens comunais, propondo, como síntese, uma ética administrativa bastante influenciada pela sua postura religiosa de frade mendicante. No capítulo 70 do De regimine rectoris, Paolino propôs a seguinte caracterização do bom governante citadino (recthor): aquele que "[...] sì entende ben comun" (MUSSAFIA, 1868 , p. 100), explicitado por ele, no capítulo 67, como aquele que "endireita a sua intenção ao bom estado do comum" (MUSSAFIA, 1868, p. 97 ${ }^{11}$; bom governante também é aquele que guarda a utilidade comum [utilitade comuna], vive segundo a razão e quer ser considerado apenas por seus cidadãos. Já o mau governante, ou tirano (tyranno), "sì entende ben proprio", ou seja, "aquele que busca propriamente a sua utilidade" (soa utilidade), aplica-se em ajuntar dinheiro (congregar pecunia), vive segundo os "afetos" (a dellecto) e quer ter a consideração dos forasteiros fazendo ofensas aos cidadãos. Segundo a interpretação de Paolo Evangelisti (2001, p. 343), Paolino não critica o tirano simplesmente porque busca o bem próprio, mas porque busca o enriquecimento. $\mathrm{O}$ frade aproxima o sentido de "soa utilidade" ao de "congregar pecunia".

Em todo o De regimine rectoris, o enriquecimento aparece de maneira muito séria: o bom governante não pode se enriquecer ao governar; o bom governo não pode fazer a cidade se enriquecer além do necessário; a riqueza pecuniária torna-se, aqui, o ponto de discórdia entre bem comum e utilidade comum. Paolino acredita que o bem comum (bon de la comunanza) deve ser desejado de maneira ilimitada, enquanto a utilidade comum (utilitade de la comunanza) conhece um limite, isto é, o tanto necessário [co fa mester] (MUSSAFIA, 
1868, p. 49). Há, portanto, um bem comum que se pode desejar sem limites e outra espécie de bem, o qual, pela sua específica característica relativa, ou instrumental, precisa ser dosada, este bem, como somos levados a concluir, são as riquezas (richeçe). As riquezas, ainda que tragam vantagem para a cidade, não podem ser desmesuradas. E por este caminho que Paolino configura o tirano: despojado de todo moralismo, o tirano obedece a uma categoria econômica: ele não se enriquece pelo empobrecimento da comuna; ele não é ladrão, ou, se o é, não é do jeito tradicional; o tirano, ao contrário, enriquece a comuna. Em Paolino, o tirano ocupa bem os qualificativos do empreendedor e do investidor que fazem o dinheiro render sempre, e aqui está o problema: o tirano enriquece a cidade por via ilícita e além do necessário: Paolino não admite que dinheiro ilícito seja somado às riquezas da cidade. Note-se ainda a consequente constatação de que o tirano não gere os bens de maneira correta, isto é, respeitando o limite das entradas e saídas de dinheiro.

O tirano de Paolino não se apropria do bem comum, que é bem absoluto, apenas insiste em dar mais valor à utilidade comum ou aos bens comunais, que são relativos. Nesse caso, ele não usurpa o poder (definição clássica de tirano), mas é um mau gestor, porque não sabe medir as exigências econômicas. A tirania é exercida, portanto, sobre os recursos (riquezas) não sobre as instituições. Dessa posição bastante inusual, Paolino agrega ao manual do bom governo outras especificações relativas à gestão dos bens comunais: os conselheiros da cidade, grupo de sábios que auxiliam o rector a desempenhar sua função, são responsáveis por fiscalizar se as "[...] entradhe della citadhe son sofficiente alle spense" (MUSSAFIA, 1868, p. 103); mas não basta serem suficientes, é preciso que também sejam lícitas: se forem, podem ser acolhidas e conservadas, se não forem, devem ser evitadas. Este conselho responsabiliza-se inclusive pela fiscalização dos preços, verificando a lei da oferta e da procura ("[...] metter certha misura a certo presio e montar lo presio e desmontar così co la citade abonda o mancha") - (MUSSAFIA, 1868, p. 104), controlando a economia para evitar o enriquecimento ilícito tanto dos comerciantes quanto das próprias instituições da cidade.

Desse modo, a questão dos bens comunais parece ser orientada pela seguinte lógica: o governante promove a acumulação de 
recursos desde que a finalidade seja justa (utilitade della citadhe), que os meios de acumulação sejam justos e que a gestão desses bens também seja justa: em todo o processo observa-se a medida certa, pois o bom governante é aquele que sabe medir. A desmedida tirânica traz dinheiro à cidade, mas faz perder o senso de solidariedade: a tirania é cruel, não confia em ninguém, prejudica os cidadãos e os estrangeiros (MUSSAFIA, 1868, p. 100).

\section{Bem comum versus bem particular}

Se admitirmos que a retórica política caracterizava o exercício profissional de homens letrados a serviço das comunas, podemos pensar que as populações comuns não tinham acesso aos discursos produzidos e proferidos no âmbito mais restrito das assembleias e dos conselhos. No entanto, essas mesmas populações estavam expostas a um outro tipo de retórica, a religiosa, que, por meio da pregação ordinária de profissionais da palavra litúrgica, os frades mendicantes, tinham a chance de acompanhar os temas debatidos pelos homens de poder e de saber nos círculos de governo: isso porque a pregação religiosa caminhava pari passu com as preocupações políticas e, em se tratando de cidades comunais, os pregadores eram homens envolvidos com os ditames da política urbana, alargando o quadro geral dos oradores cívicos. Dentre os pregadores que mais se ocuparam de problemas comunais encontra-se Giordano de Rivalto (ou de Pisa) (1260-1311): ele é frade dominicano como Tomás de Aquino, mas, ao contrário de Tomás, não foi um magister, mas praedicator. E, dentro do campo da pregação, não acalçou a celebridade de um Antônio de Pádua ou Bernardino de Siena, o que nos dá a chance de ver um pregador "médio" em ação, próximo às populações de sua cidade, no caso, Florença, num arco cronológico bastante alargado.

Nesse contexto, a pregação é algo fundamental, pois é um instrumento de comunicação de massa (D'AVRAY, 1985, p. 3) durante toda a Baixa Idade Média, senão antes. Temos milhares de relatos que indicam que os pregadores falavam às multidões; e temos milhares de manuscritos que registram milhares de sermões ${ }^{12}$. É instrumento de comunicação, de formação moral, religiosa, mas 
também cultural e linguística, haja vista as pregações nos diversos vernáculos dos séculos XIII-XIV. Nicole Bériou (2002), por exemplo, chega a afirmar que os sermões podem ser interpretados como escolas de educação política, talvez a única oportunidade em que as pessoas iletradas podiam ter contato com um discurso erudito. Os sermões recorrem à filosofia, à história, à cosmologia, à geografia: por meio dos sermões, gente iletrada tinha acesso a um cabedal de referências que jamais teria sem a pregação. Giordano de Pisa (ou de Rivalto), por exemplo, quando queria pregar sobre o valor do bem comum, que costuma ser tema filosófico e político, recorria à história de Roma e falava da vida de Augusto ou de Cipião Africano. Giordano sincronizava o passado romano ao presente florentino, chamando a república romana de "comuna de Roma": é muito difícil supor que o frade não soubesse a diferença entre a república de Roma e a comuna de Florença. A meu ver, ele estava adaptando o saber erudito, acessível a poucos, para o seu público, como faz um mestre quando ensina história às crianças.

A pregação acontecia desde um púlpito (VECCHIO, 1998, p. 132), geralmente externo à igreja, em frente à praça. $\mathrm{O}$ púlpito, fixo ou improvisado, era um lugar de poder: o poder da palavra e, ao mesmo tempo, o poder do sagrado; mas também era um lugar político, já que a palavra pregada visava à ordenação da vida cívica. A partir do púlpito, sobretudo no caso dos frades mendicantes, reconhecemos a proposição de uma ética orientada a combinar-se com a retórica citadina comum e, ao mesmo tempo, propondo referências morais de maior autoridade. A pregação mendicante possui caráter social declarado, porque ela não se esgota na explicação bíblica ou exortação religiosa: é também e sobretudo a proposição de modelos de conduta adaptados ao agir laico (RUSCONI, 1981, p. 984). Tratava-se de particularizar as mais diversas categorias sociais e dar a elas uma cartilha ética correspondente ao agir cristão em cada estado de vida: tratava-se de "laicizar" os conteúdos da fé, isto é, encarná-los em gêneros de vida compatíveis com as cidades. Como mostra Cecilia Iannela (2002), a pregação dominicana era extremamente atenta aos modos de vida do auditório que se pretendia converter.

A obra sermonária de Giordano é muito vasta: conhecemos 726 sermões, destes, 399 foram pregados em Florença. Para nossos 
intentos, é muito bom que esses sermões tenham chegado a nós por meio de reportationes, isto é, pelas anotações de escribas, geralmente leigos taquígrafos (reportatores) que sumariavam aquilo que ouviam no ato da prédica. As reportationes levam-nos a perceber os sermões reais, não os modelos de sermões que nunca saberemos se foram proferidos. A reportatio permite-nos descobrir a data e a cidade em que cada sermão foi pregado; informa-nos sobre o público e, às vezes, até mesmo a situação climática. O cuidado dos taquígrafos nos presenteia, atualmente, com muitas respostas quando se trata de compreender o valor social da pregação.

É a partir destas considerações que iremos recorrer a Giordano de Pisa, tomando o sermão Sicut laetantium omnium est in te, proferido em vulgar toscano, em 12 de abril de 1304, em Florença. A leitura sociológica que o frade apresentou em sua prédica nos faz ver o peso da teologia de Agostinho de Hipona: Giordano retoma a premissa agostiniana do coração humano cindido: há algo no homem que quer o bem comum, porque sabe que não pode viver sozinho; mas há algo nele que também quer o bem particular, porque é seduzido pelo amor que sente por si mesmo. Nisso, Giordano mostra ter sido atento leitor de santo Agostinho: em primeiro lugar, pela concepção de uma luta interna no coração do homem; depois, pela concepção do efeito social do pecado, que decorre da premissa de que um homem cindido torna viciadas todas as suas ações. A finalidade social da pregação é, sobretudo, mostrar essa tendência à autodestruição que reside no interno da comunidade humana; no centro de Florença, do alto do púlpito, Giordano queria recordar aos florentinos imersos em rixas e disputas que o fundamento mesmo de suas ações podia destruir a cidade e, então, de nada adiantaria ter muito dinheiro.

Num sermão citado por Cecilia Iannela (2002, p. 175), Giordano declara: "[...] enquanto os cidadãos de Roma amaram o bem comum, eles tiveram o senhorio sobre todo o mundo; mas, ao passo que começaram a amar o bem próprio, perderam a senhoria, destruíram-se e não sobrou nada". A referência é sempre a história romana, como se pode ver num outro sermão: 
E porque o bem de Deus é digno de tanto louvor e de tanta glória, assim também os mundanos se esforçam em agir principalmente no bem comum e estes foram aqueles que conquistaram grande nome e grande glória sobre todos os outros. Assim aconteceu com Augusto que procurou o bem da república e fê-la crescer desmesuradamente que recebeu o nome Otaviano e foi tido em grande reverência pelos romanos [...]; e vendo os antigos que o bem comum era tão útil e digno de tanta glória, se esforçaram com maior rigor a viver no bem comum. E assim se puseram em batalhas, em perigos, e em grandes atos, de onde pudesse vir grande utilidade a toda a comuna (il comune), assim como fez Cipião Africano, que se expôs a grandes perigos e a grandes coisas para libertar e salvar a comuna de Roma e foi ele que libertou os romanos de sua última destruição; por isso foi digno de muito louvor, conseguiu um nome grandíssimo, grande glória, porque procurou o bem comum e foi útil a todas as pessoas (IANELLA, 2002, p. 176, nota 13).

A oposição entre o bem comum e o bem privado acentua a diferença entre a paz e a guerra, a ordem e a desordem: amar o bem privado e colocá-lo acima do bem comum torna-se obstáculo para a aquisição da paz temporal: “[...] se o homem amasse o bem comum de todos, oh, quanta paz e quanto bem existiria [...]" (IANELLA, 2002, p. 178). Esta mesma tônica persiste no sermão Sicut laetentium omnium: alegria misturada à tristeza. O tema da mistura apela, mais uma vez, à teologia de Agostinho: não há possibilidade de pureza no tempo histórico, porque o coração humano é fragmentado, tencionado, cindido. Giordano, nesta prédica, parte da exposição alegórica de três cidades (a terrena, a celeste, a infernal): a cada uma corresponde um tipo de cidadão e, consequentemente, de prática ética. Comparando a cidade terrena, Florença de 1304, à cidade do inferno, Giordano acusa os florentinos de serem peritos na "arte de pecar"

Quanto pecado, quanto vício, quanta sujeira por toda a cidade! Ora, não é este mundo um outro inferno, não se faz 
continuamente aqui aquilo que é feito no inferno? Todas as boas artes, que antigamente se costumam fazer, todas elas, hoje, estão corrompidas e falseadas e não há uma boa arte sem pecado. Quanto encontraremos da arte do paraíso, daqueles que estão em pureza, santidade e castidade? (NARDUCCI, 1867, p. 144-145) ${ }^{13}$

Florença, no tempo de Giordano, era uma cidade muito rica, em que as artes ou corporações de ofício constituíam o coração político da comuna. Tudo está corrompido: as corporações deixaram-se guiar pelo espírito do inferno que é o amor pelo bem privado. Sabemos quais são as "artes" corrompidas olhando para um outro sermão: "Vejam, pois, as artes corrompidas, e me refiro especialmente à arte da lã e da mercadoria que se pratica muito nesta cidade" (BARONE, 1977, p. 613) ${ }^{14}$ : tecelagem e comércio, grandes fontes de riqueza em Florença. Em ambas as artes, a estrutura recorrente é o lucro desenfreado, o qual Giordano critica com fervor. Amor pelo lucro; amor pelo bem privado. Para Giordano, como para Agostinho, também há amor no inferno, o amor por si mesmo (cupiditas); aqui está o tema dos dois amores que geram duas cidades, como explica Agostinho, no livro XIV, 28 de seu De civitate dei: o amor por Deus até o desprezo por si mesmo, a cidade de Deus; o amor por si mesmo até o desprezo de Deus, a cidade do demônio.

Giordano como que populariza a discussão erudita de Agostinho; ele encarna o problema agostiniano no coração da situação histórica de Florença. O bem comum está inseparavelmente ligado a este amor que torna a cidade terrena mais parecida com a cidade do céu. Pode até ser que haja algum cidadão do céu neste mundo, mas, se houver, são poucos. Este mundo é mais inferno do que céu. Daí que o lugar da alegria pura, sem mistura de tristeza, só existe entre os bem-aventurados, porque esses não imitam os demônios, isto é, não conhecem a arte de pecar. No entanto, a cidade terrena pode vir a ser melhorada, e o método é a fuga. Giordano manda que os cidadãos fujam do pecado. Prestemos atenção no processo: cada cidadão, individualmente, é que deve fugir, pois a fuga coletiva parece impossível. 
[...] tu não deves pensar nos atos alheios; foge tu e escapa, salva-te, não prestes atenção nos outros: a quem é dada a graça de escapar, de fugir, que fuja e escape do mesmo modo que na derrota todo homem escapa como pode, e não cuida então dos demais, mas escapa e foge o quanto pode (NARDUCCI, 1867, p. 145) ${ }^{15}$

A salvação da alma individual, que parece mostrar que ela vale mais do que o bem comum, não deve atrapalhar nossa análise do sermão de Giordano. O frade não perde de vista a coletividade, e aqui está seu segredo: se ele, como pregador, conseguir fazer com que cada ouvinte fuja ao pecado e se refugie na penitência, terá feito com que toda a cidade fuja, parte por parte, individualmente. Toda a cidade, formada pelos muitos indivíduos, ver-se-á longe do inferno e perto do céu.

Giordano pregou o sermão em 12 de abril, provavelmente durante a quaresma, haja vista que, no fim da prédica, ele evoca o exemplo daqueles que, antes da quaresma, fazem propósitos de penitência, mas, depois que ela começa, logo desanimam. Quaresma, aqui, é uma metáfora da penitência feita na terra: se se faz, entra-se na alegria dos santos; se não se faz, entra-se na quaresma do inferno. A penitência age sobre a capacidade dos homens de amar: ela leva os homens a amar aquilo que deve ser amado: todos amam, porém, nem todos sabem o que amar. Donde o frade conclui: “Ter dileção não é coisa má e nem desagrada a Deus enquanto ele é amado, e se não misturamos outro" (NARDUCCI, 1867, p. 146). É assim que Giordano termina seu sermão conclamando os ouvintes a seguirem o exemplo dos santos que fizeram desta vida uma quaresma, isto é, uma marcha penitencial rumo ao bem e agora gozam a alegria plena. Os santos são aqui propostos como modelos de cidadãos: em primeiro lugar, porque o são de fato, no céu. Em segundo, porque, pelo modelo que oferecem, podem ajudar os cidadãos da terra a edificar uma cidade melhor, ou seja, pelo amor do bem comum que começa em Deus e que é extensivo a toda a vida comunitária animada pela ética do céu, onde só se ama o que deve ser amado.

A proposta de Giordano faz com que vejamos o quanto os florentinos, apesar de construírem uma cidade rica e regionalmente 
Relações de poder e bem comum na Baixa Idade Média Italiana...

poderosa, não encontravam consenso em torno da ideia de bem comum e sua política e, nesse sentido, eram como os milites de Perúgia. Descrente de qualquer ação social por si mesma imbuída de comunitarismo e senso do bem comum, o frade apelava para os paradigmas religiosos de uma pátria celestial em que o bem de todos era amado por todos e a todos garantia a alegria: Deus. Ora, é certo que tal discurso encaminha a reflexão política para um âmbito que, para nós, escapa à definição cívica, mas a descrença de Giordano provinha da observação do movimento histórico na cidade em que passou boa parte da vida. A lógica do ganho e da acumulação, o entesouramento individual, para ele, contrastavam com a compreensão de uma comunidade movida pela caridade e, por isso, o bem comum, que instaura a communitas, precisava ser buscado além da própria comunidade, ou melhor, numa comunidade transcendida, elevada acima do desejo de acumular moedas (cupiditas): as vicissitudes da história de Florença reforçaram a ideologia dos frades mendicantes que, no deserto deste mundo, queriam construir cidades celestiais.

Ora, bem antes de Giordano de Pisa ter feito esta pregação, Antônio de Pádua (1195-1231) redigiu o Sermão para a natividade de São João Batista (24 de junho) no qual, apoiando-se na Glosa Ordinária, afirmou que "[...] o nascimento dos santos traz alegria a muitos, porque é um bem comum; isto é, os santos nascem para a utilidade comum" (COSTA, 1979, p. 265) ${ }^{16}$. De fato, a festa dos santos alegra os homens na terra e, nesse sentido, eles pertencem a toda comunidade cristã; mas, é bastante interessante notar que o nascimento deles está relacionado à utilidade comum, como que a reforçar a ideia de que os homens, sozinhos, são incapazes de instaurar uma ordem social que garanta a segurança e o bem-estar. A premissa de que os cidadãos do céu, que pelejaram sobre a terra por tempo limitado, formam uma comunidade-referência é tão antiga quanto o próprio cristianismo; no entanto, a insistência com que os pregadores dos séculos XIII-XIV, mendicantes como Antônio ou Giordano, chama a atenção para aspectos políticos estranhos para nós, mas pertinentes ao pensamento antigo, com quem os pregadores dialogavam.

Em termos aristotélicos, o bem comum é a finalidade da comunidade política e, ao mesmo tempo, seu ponto constitutivo: é 
a finalidade última e por isso a mais elevada. O pensamento cristão aproveita o substrato antigo e o transforma: o bem comum é apenas um meio de se alcançar a finalidade última. Tomás de Aquino (1225-1274), em sua Summa contra Gentiles (L III, c. 17) já escrevia:

O bem particular ordena-se ao bem comum como a seu fim; o ser da parte existe em função do ser do todo: donde o bem do povo é mais divino que o bem de um só homem. Por sua vez, o sumo bem, que é Deus, é o bem comum, de quem depende o bem de todos. (MODDE, 1949, p. 224) ${ }^{17}$

Esta afirmação de Tomás faz com que entendamos que, no debate sobre a natureza e a finalidade do bem comum, encontra-se sempre a característica metafísica que dá consistência tanto à comunidade política (communitas politica) quanto ao próprio universo. Em outras palavras, a discussão política que confere importância ao bem comum é fundamentalmente referida a esta base metafísica da qual dependem os seres, as relações e os fins próprios dos simples indivíduos ou das coletividades, tomadas como entes. É preciso destacar, com Modde (1949, p. 235), que o “[...] bem comum que é Deus” ou que dele deriva identifica-se com aquilo que, em Tomás, relaciona-se com a finalidade (o fim) última dos seres: o bem comum nada mais seria do que a finalidade comum na medida em que todos os seres tendem a um fim semelhante. No entanto, os homens, dotados de razão, não agem apenas guiados pela inclinação natural: a racionalidade os coloca em condição de construir seu destino e, portanto, de agir a favor ou contra a inclinação natural, desviando-se de seu fim último. Neste sentido, os homens precisam pôr em ação a sua razão e a sua vontade para se voltarem a este bem comum universal (o fim último) e fazem isso por meio da construção de um bem comum social, que nada mais é do que uma finalidade intermediária (utilitas communis): a vida social possui também um bem comum, mas ele não é o fim 
último, se bem que tenda para ele: para a aquisição deste fim último surge a cidade (communitas civilis) como instrumento e condição.

É nesse sentido que o nascimento dos santos constitui um bem comum: ao amarem a Deus, eles alcançaram a finalidade última e ao viverem segundo esta lógica, construíram, na terra, o bem comum social (utilitas communis) que prepara, embora não seja, a finalidade mais elevada do homem racional.

\section{Considerações finais}

Ao discutir o bem comum no pensamento político da Baixa Idade Média, Kempshall (1999, p. 24) escreve:

Classificar a finalidade da sociedade política como bonum commune significa analisar a conexão entre o bem na comunidade humana e o bem no universo; classificar a finalidade da sociedade política como communis utilitas significa analisar a conexão entre a vantagem material e o bem moral.

A communis utilitas, como vimos, é compreendida como bens contingentes necessários à vida comum: são pastagens, florestas, prados, rios e canais, estradas, moinhos e todas as coisas que as cidades possuíam coletivamente e geriam coletivamente; na linguagem tomasiana, a utilidade comum é o meio pelo qual se chega ao bonum commune, que é entendido como aquele fim último que garante aos homens a felicidade: nesse sentido, é algo sobrenatural. Pelos documentos analisados, pudemos acompanhar os meandros de uma discussão nem sempre uniforme que apontava para a mesma direção: o bem comum é definido segundo uma moral que jamais é neutra, isto é, que sempre se posiciona para valorar o bem e o mal: em outras palavras, o bem comum emerge de um consenso moral em torno da ideia de bem, um pressuposto metafísico, portanto. Os valores partilhados pelas sociedades comunais congregavam essas mesmas sociedades, pois a crença de que o bem é constitutivo do ser era comum a todas elas. Além disso, acreditava-se unanimemente que a sociedade 
é mais do que a soma de suas partes e, por isso, o bem comum não é a simples somatória dos bens particulares: a sociedade é como um homem, inteiro na união de seus componentes, mas simultaneamente corpo e espírito: a soma das partes não esgota o sentido de seu ser, pois, sendo pessoa, conceito inteiramente cristão, o homem tende a dois fins: um terreno, a vida política, e outro espiritual, a vida divina.

Desse modo, a ambiguidade da noção de bem comum, longe de nos pôr diante de uma teocracia ou de um simplório teocentrismo medieval, reconduz à análise que fazemos para aspectos, de fato, políticos, porque referidos à vida pública; compreendo "vida pública” segundo os termos expostos por Arendt (2007, p. 33), isto é, como uma segunda vida, diferente daquela privada do lar; uma e outra são diametralmente opostas, se bem que complementares: enquanto a vida doméstica aponta para o próprio (idion), a vida pública, para o comum (koinon): é assim que os autores dos séculos XIII e $\mathrm{XIV}$, aqui consultados, distinguiam a domus (o lar) da civitas (a cidade), frenquentemente chamada de res publica. Dentro desta "segunda vida", a retórica funcionava como instrumento facilitador do consensus civium, fruto de deliberação entre muitas vontades discordantes. A ação política, neste caso, aspirava a ordenar a comunidade dos homens não pelo despotismo do chefe de família, mas pelo civilismo dos cidadãos que, mediante leis, estatutos, jurisprudência, contratos, acordos, discursos, construíam uma cidade, uma communitas, não uma domus privada, como afirmava Arendt, pois o bem comum e a utilidade comum referiam-se eminentemente à esfera pública.

\section{POWER RELATIONS AND THE NOTION OF THE COMMON GOOD IN ITALY DURING THE LATE MIDDLE AGES (XIII-XIV CENTURIES)}

Abstract: This paper aims to discuss the understanding of the common good/ common benefit in political practices of the late Middle Ages. We want to discuss about the possibility of existence of the political action and the political sphere in the medieval period and grasp how theses factors constituted criteria of sociability and governance. Common good is understood as a means of putting civil life in order, but which transcends the historical actors and institutions: indeed the common good is the benchmark of social practices which aims at the the common benefit and, as being accessible to citizens and institutions, makes 
collective life and social justice possible.

Keywords: Common good. Common benefit. Politics. Communal city.

\section{Notas}

${ }^{1}$ A expressão portuguesa "partidos" pretende traduzir os vocábulos latinos partes/ partialitates que foram usados por autores da Baixa Idade Média, como Giordano de Pisa, Remigio dei Girolami e Bartolus de Sassoferrato, para fazer referência aos grupos urbanos rivais que disputavam o poder nos governos citadinos, como os Guelfos e Gibelinos, os Geremei e Lambertazzi (no caso de Bolonha), ou o Popolo e os Milites, em Perúgia. No Tractatus de Guelphis et Gebellinis, Bartolus assim se expressou: "[...] sunt duo partes, quarum una regit civitatem, altera stat deiecta sed alio tempore rexit", ou ainda: "quaedam sunt civitates et castra, que simpliciter reguntur absque alicuius partialitatis nomine [...]" (Apud COSTA, 2012, p. 204); no Sermão para o terceiro domingo da Quaresma (Omne regnum in se ipsum divisum desolabitur), pregado entre 1298-1301, o dominicano Remígio dei Girolami assim se referia aos grupos urbanos em disputa: "Fracta est civitas magna in tres partes. Una fractio est quia Guelfi dicunt male de Ghibellinis quod non cedunt, et Ghibellini de Guelfis quod expellere eos volunt [...]" (Apud ZORZI, 2008, p. 85).

${ }^{2}$ Rettorica, 9: Et sopra ciò la tema é cotale: Furono uomini folli sanza discrezione, li quali, veggendo che alquanti erano in grande onoranza e montati in alto stato per lo bello parlare ch'usavano secondo li comandamenti di questa arte, sì studiaro solo in parlare e traslasciaro lo studio di sapienzia, e divennero sì copiosi in dire che, per l'abondanza del molto parlare sanza condimento di senno [senso/juízo], che cuminciaro a mettere sedizione e distruggimento nelle cittadi e ne'comuni et a corrompere la vita degli uomini.

${ }^{3}$ Tresor, III, 2: Et Tuilles dist que la plus haute science de cité governer si est rectorique, c'est a dire la science du parler; car se parleure ne fust cités ne seroit, ne nus establissements de justice ne de humaine compaignie.

${ }^{4}$ Tresor, III, 73, 5-6: Et cil sont en ii manieres; uns ki sont en France et es autres païs, ki sont sozmis a la signorie des rois et des autres princes perpetueus, ki vendent les provostés et les baillent a ciaus ki plus l'achatent (poi gardent sa bonté ne le proufit des borgois); l'autre est en Ytalie, que li citain et li borgois et li communités des viles eslisent lor poesté et lor signour tel comme il quident qu'il soit plus proufitables au commun preu de la vile et de tous lor subtés.

${ }^{5}$ Tresor, III, 74, 4: [...] car li sires doit amer ses subtés de grant cuer et de clere foi, et veillier de jour et de nuit au commun proufit de la vile et de tous homes. 


\section{André Luis Pereira Miatello}

Tot autresi doivent il amer lor signour a droit cuer et a veraie entention, et doner li conseil et aide a maintenir son office; car a ce ki n'est k'un seul entr'aus, il ne poroit rien fere se par aus non.

${ }^{6}$ De regimine rectoris, 35: Dredo sì bon segnor se de' amar la comunança, perciò ke dredo el [creator] comunança è mejor, kè ella comprendhe bontade de tuti li particular, onde per deffender questo ben comun se de' meter çascun particular, sì co se mete la man per deffender la vita de tuto lo corpo. Dredo çò de' amar quelli ke è mejor alla comunança o sia per oracion, o sia per conseji o per officii o per artificii, e questo vol vertude de justicia en lo capitolo IX.

${ }^{7}$ Autores como Castagnetti (1983), Menant (2004) e Panero (2008) têm insistido em contrariar a tradicional oposição, muito comum na historiografia, entre uma suposta burguesia citadina e os senhores castelões que antecipa, para o século XIII, um conflito que pertence mais propriamente ao século XVIII. As comunas (rurais ou urbanas), como disse, são oriundas de um processo de negociação com os poderes aristocráticos e não de processos revolucionários.

${ }^{8}$ Liber Paradisus: De quarterio porte sancti Proculi. Paradisum voluptatis plantavit dominus deus omnipotens a principio, in quo posuit hominem quem formavit et ipsius corpus ornavit veste candenti, sibi donans perfectissimam et perpetuam libertatem. Set ille miser sue dignitatis et divini muneris immemor, pomum vetitum supra preceptum dominicum degustavit, unde se ipsum et omnem suam posteritatem in hanc vallem misere traxit et humanum genus enormiter tossicavit aligans id miserabiliter nexibus diabolice servitutis et sic de incorruptibili factum est corruptibile, de immortali mortale, subiacens alterationi et gravissime servituti. [...] Cuius rei consideratione nobilis civitas Bononie que semper pro libertate pugnavit, preteritorum memorans et futura providens in honorem nostri redemptoris domini Iesu Christi nummario pretio redemit omnes quos in civitate Bononie ac episcopatu reperit servili condictione adstrictos et liberos esse decrevit inquisitione habita diligenti, statuens ne quis adstrictus aliqua servitute in civitate vel episcopatu Bononie deinceps audeat commorari, ne massa tam naturalis libertatis quam redempta pretio, ulterius corrumpi possit fermento aliquo servitutis, cum modicum fermentum totam massam corrumpat et consortium unius mali bonos plurimos dehonestet. [...] factum est memoriale presens, quod proprio nomine debet vocari merito Paradisus continens dominorum nomina servorum et etiam ancillarum ut liqueat quibus servis et ancillis est acquisita libertas et quo pretio, scilicet X librarum pro maiore XIIII annis servo et ancilla et octo librarum bononinorum pro minore constituto cuilibet dominorum pro quolibet qui detinebatur adstrictus vinculo servitutis.

9 "ut omnes communitates... per portas et parrochias secundum quantitatem et qualitatem hominum dividantur".

Anos 90, Porto Alegre, v. 20, n. 38, p. 181-217, dez. 2013 
${ }^{10}$ Embora o Tractatus de Guelphis et Gebellinis, de Bartolus de Sassoferrato, não tenha sido proposto à discussão neste texto, há que se lembrar que o mesmo pode ser tomado como importante síntese das diversas posturas relativas ao entendimento de bonum commune; na opinião de Bartolus, o bonum publicum manifesta-se pela sobreposição dos interesses particulares das diversas partes (partialitates) porque o que se tem em vista é a res publica à qual todas as partes devem convergir (COSTA, 2012, p. 205).

${ }^{11}$ De regimine rectoris, 67: "el ke dreza la soa entencion a bon stado del comun". ${ }^{12}$ A título de exemplo, gostaria de mencionar o levantamento realizado por Johannes Baptist Schneyer, entre 1969-1990, intitulado Repertorium der Lateinischen Sermones des Mittelalters, que recolhe apenas os sermões em língua latina, cadastrando as primeiras e últimas frases de cada sermão identificado, com o respectivo código de manuscrito; o repertório de Schneyer contabilizou 100 mil sermões pregados entre 1150-1350, os quais, quando indicados na obra, totalizaram 11 volumes e mais de 7.300 páginas (MUESSIG, 2002, p. 75).

${ }^{13}$ Sermo Sicut laetantium omnium: "Ogni peccato, ogni vizio, ogni sozzura per tutta la Cittade. Or non è questo mondo un altro ninferno, non si fa continuamente qui che nel ninferno? Tutte le buone arti, che anticamente si solieno fare, tutte son oggi corrotte e falsate, e non ci si fa oggi una buona arte sanza peccato. Or quanta ci troverai dell'arte di paradiso, di quelli che sieno in purità, in santità, in castità?" 14 "Vedi adunque l'arti corrotte, e specialmente ho detto di questa arte della Lana e de la mencatìa che si fa più in questa città".

${ }^{15}$ Sermo Sicut laetantium omnium: "non n'hai tu a pensare i fatti altrui, tu fuggi e scampa, e salva te, non ti caglia degli altri, a cui è data grazia di scampare, di fuggire; fugga e scampi: come nella isconfitta, ogni uomo campa chi puote, e non si cura allora degli altri, ma scampa egli e fugge quanto puote".

${ }^{16}$ Sermo in nativitate sancti Ioannis Baptistae, 4: "Habet sanctorum editio, idest, nativitas, laetitiam plurimorum, quia commune bonum est, idest, sancti ad communem utilitatem nascuntur".

17 "Bonum particulare ordinatur in bonum commune sicut in finem; esse enim partis est propter esse totius: unde et bonum gentis est divinius quam bonum unius hominis. Bonum autem summum, quod est Deus, est bonum commune, cum ex eo universorum bonum dependeat".

\section{Referências}

ARENDT, Hannah. A condição bumana. Tradução de: Roberto Raposo. 10 ed. Rio de Janeiro: Forense Universitária, 2007. 


\section{André Luis Pereira Miatello}

ARTIFONI, Enrico. Retorica e organizzazione del linguaggio politico nel Duecento italiano. In: Le forme della propaganda politica nel Due e nel Trecento. Relazioni tenute al convegno internazionale di Trieste. Roma: École Française de Rome, 1994. p. $157-182$.

BARONE, Giulia. L'Ordine dei predicatori e le città. Teologia e politica nel pensiero e nell'azione dei predicatori. In: Mélanges de l'École française de Rome. Moyen Âge, Temps Modernes. v. 89, n. 2, 1977. p. 609-618.

BÉRIOU, Nicole. Un mode singulier d'éducation. La prédication aux derniers siècles du Moyen Âge. In: Communications. v. 72, 2002. p. 113-127.

CAMMAROSANO, Paolo. L'éloquence laïque dans l'Italie communale (fin du XIIe-XIVe siècle). In: Bibliothèque de l'École des Chartes. v. 158, n. 2, 2000. p. 431-442.

CARMODY, Francis J. Li Livres dou Tresor. Édition critique. Genève: Slatkine Reprints, 1998.

CASTAGNETTI, Andrea. Le comunità rurali dalla soggezione signorile alla giurisdizione del comune cittadino. Verona: Libreria Universitaria Editrice, 1983.

COLLARD, Franck. Pouvoir d'un seul et bien commun (VIè-XVIè siècles). In: Révue Française d'Histoire des Idées Politiques. n. 32, v. 2. p. 227-230, 2010.

COSTA, Beniamino et alii (Org.). S. Antonii Patavini Sermones Dominicales et Festivi. Vol. III Sermones festivi. Pádua: Edizioni Messaggero, 1979.

COSTA, Pietro. Bonum commune e partialitates: Il problema del conflitto nella cultura político-giuridica medievale. In: Il bene comune: Forme di governo e gerarchie socieali nel Basso Medioevo. Atti del XLVIII Convegno storico Internazionale (Todi, 9-12 ottobre 2011). Spoleto:

CISAM, 2012. p. 193-216.

DALARUN, Jacques. Gouverner c'est servir: essai de démocratie médiévale. Paris: Alma, 2012.

D'AVRAY, Donald. L. The Preaching of the Friars. Sermons diffused from Paris before 1300. Oxford: Clarendon Press, 1985.

EVANGELISTI, Paolo. I pauperes Christi e i linguaggi dominativi. I francescani come protagonisti della costruzione della testualità politica e dell'organizzazione del consenso nel bassomedioevo (Gilbert de Tournai, Paolino da Venezia, Francesc Eiximenis). In: La propaganda politica nel Basso Medioevo. Atti del XXXVIII convegno storico internazionale, Todi, 2001. Spoleto: CISAM, 2002. p. 315-392. FOSSIER, Robert. Les franchises rurales en Europe occidentale au Moye Âge: fondements et problèmes. In: Liberté et libertés. VIII centenaire de la charte des franchises d'Aoste. Aosta: Archivio Storico Regionale, 1993. p. 39-54.

Anos 90, Porto Alegre, v. 20, n. 38, p. 181-217, dez. 2013 
FOUCAULT, Michel. Omnes et singulatim': uma crítica da Razão política. In: DA MOTTA, Manoel Barros (Org.). Michel Foucault estratégia, poder-saber. Coleção Ditos e Escritos IV. Rio de Janeiro: Forense Universitária, 2003. p. 355-385.

GATTA, Francesco Saverio; PLESSI, Giuseppe. Liber Paradisus con le riformagioni e gli statuti connessi. Bolonha: Tipografia Luigi Parma, 1956.

GILLI, Patrick. Política e instituições: as quatro idades das cidades italianas. In: Cidades e sociedades urbanas na Itália Medieval (séc. XII-XIV). Campinas: Editoria Unicamp/UFMG, 2011.

GILLI, Patrick; THÉRY, Julien. Le gouvernement pontifical et l'Italie des villes au temps de la théocratie (fin XIIe-mi-XIVe s.). Montpellier: Presses Universitaires de la Méditerranée, 2010.

IANNELA, Cecilia. Predicazione domenicana ed etica urbana tra Due e Trecento. In: Predicazione e società nel medioevo: riflessione etica, valori e modelli di comportamento. Atti/Proceedings of the XII Medieval Sermon Studies Symposium. Padova, 14-18 Luglio 2000. Pádua: Centro Studi Antoniani, 2002. p. 171-185.

JANSEN, Philippe. La rhétorique, base et horizon thématique du savoir politique dans l'Italie médiévale. In: Noesis. n. 15 [Le savoir peut-il se passer de rhétorique?], 2010. p. 157-178.

JAEGER, Stephen C. The enyy of Angels. Cathedral schools and social Ideals in Medieval Europe (950-1200). Filadélfia: University of Pennsylvania Press, 1994.

MAGGINI, Francesco (Ed.). La Rettorica di Brunetto Latini. Pubblicazioni del Reale Istituto di studi superiori pratici e di perfezionamento in Firenze. Florença: Galleti e Cocci, 1915.

MAIRE VIGUEUR, Jean-Claude. Cavalieri e cittadini. Guerra, conflitti e società nell'Italia comunale. Tradução italiana de: Aldo Pasquali. Bolonha: Il Mulino, 2004.

MENANT, François. Les chartes de franchise de l'Italie communale: un tour d'horizon et quelques études de cas. In: BOURIN, Monique et alii (Org.). Pour une anthropologie du prélèvement seigneurial dans les campagnes médiévales (XIe-XIVe siècles). Réalités et représentations paysannes. Paris: Publications de la Sorbonne, 2004. p. 239-269.

. Pourquoi les chartes de franchise italiennes n'ont-elles pas de préambules? In: BOURIN, Monique; MARTÍNEZ SOPENA, Pascual. Pour une anthropologie du prélèvement seigneurial, II. Les mots, les temps, les lieux du prélèvement. Paris: Publications de la Sorbonne, 2007. p. 253-274.

MILANI, Giuliano. Partecipare al comune: inclusione, esclusione, democrazia. In: Il Governo delle città nell'Italia comunale. Una prima forma di democraz̧ia? Atti della giornata di studi. Prato 12 ottobre 2005. Bolletino Ronciniano. v. VI, 2006. p. 35-49. 


\section{André Luis Pereira Miatello}

MODDE, André. Le Bien Commun dans la philosophie de saint Thomas. In: Revue Philosopbique de Louvain. Troisième série. Tomo 47, n. 14, 1949. p. 221-247. MUESSIG, Carolyn. Sermon, preacher and society in the Middle Ages. In: Journal of Medieval History. v. 28, 2002, p. 73-91.

PANERO, Francesco. Signori e servi: una conflittualità permanente. In: BOURIN, Monique et alii (Org.). Rivolte urbane e rivolte contadine nell'Europa del Trecento. Un confronto. Florença: Firenze University Press, 2008. p. 305-321.

PINI, Antonio Ivan. Città medievali e demografia storica. Bolonha, 1996.

ROSANVALLON, Pierre. Por uma bistória do político. Tradução de: Christian Edward Cyrill Lynch. São Paulo: Alameda, 2010.

RUSCONI, Roberto. Predicatori e predicazione (secoli IX-XVIII). In: VIVANTI, Corrado. Storia d'Italia. Intelletuali e potere. Annali 4. Turim: Giulio Einaudi Editore, 1981. p. 950-1035.

VECCHIO, Silvana. Il Liber de Introductione Loquendi di Filippo da Ferrara. In: I Castelli di Yale. v. 3, 1998. p. 131-138.

ZORZI, Andrea. Fracta est civitas magna in tres partes. Conflitto e costituzione nell'Italia comunale. In: Scienza e Politica. v. 39, 2008. p. 61-87.

Recebido em: 26 de agosto de 2013. Aprovado em: 18 de setembro de 2013. 